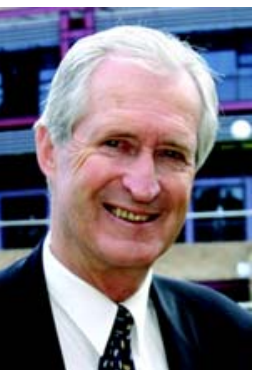

\title{
Obituary
}

\section{John Hugh Wilson Hogg oAm, MBBS, FRACS, FRCS, FRCSI, DDU}

JoHN HogG was a true all-rounder - sportsman, explorer, sailor and skier, as well as surgeon, devoted husband and father, and academic. He died at home on 1 March 2013 from metastatic melanoma.

John was born in Sydney on 10 January 1943 and was educated at Trinity Grammar School, where his father, James Wilson Hogg, was headmaster.

After graduating in medicine from the University of Sydney in 1967, he spent 2 years at Royal Prince Alfred Hospital.

In 1969, John went to Antarctica for 15 months with the Australian National Antarctic Research Expedition as team doctor and second in command, leading several expeditions there. The Hogg Islands, near Australia's Mawson Station, are named after him. He then travelled to the United Kingdom, where he achieved Fellowships of the Royal College of Surgeons and the Royal College of Surgeons in Ireland.

John returned to Australia in 1975, and worked at Royal Prince Alfred Hospital, focusing on vascular surgery. He obtained Fellowship of the Royal Australasian College of Surgeons and was a member of the first Australian Surgical Team to visit China.

In 1976, John married Linda Blogg, a physiotherapist. They moved to Wollongong, where John established his busy general and vascular surgical practice, and they had two sets of twins within 3 years.

John and Linda established IOH, an occupational health facility, in 1984 and, in 1989, John cofounded the South Coast Vascular Laboratory.

In 2002, John and Linda took a holiday to Bali, only to end up working around the clock supporting victims of the Bali bombing. For their outstanding work there, they were each awarded a Medal of the Order of Australia. John was also named Wollongong Citizen of the Year in 2003.

Elected Chair of the Illawarra Medical Staff Council in 2003, John was appointed Clinical Director of Surgery for northern Illawarra hospitals.

From 2004 to 2008, John was the Foundation Dean of the Graduate School of Medicine at the University of Wollongong. On retiring in 2008, he was appointed Emeritus Professor. John also chaired the Light of Hope Foundation, supporting people with mental illness in the Illawarra region. Later in 2013, he will posthumously receive an honorary doctorate of science from the University of Wollongong.

John Hogg lived his life to the full, achieving a nearperfect balance between enjoyment and achievement. His enormous contribution and legacy live on.

Stephen E J Andersen doi: 10.5694/mjal3.10545 